of such elements in arrays arising in this connexion are 10,136 , etc.

In this light, it is interesting to speculate if at least some of the dissimilarities between the proton and the electron are not somehow bound up with the question of degrees of freedom, and, in particular, if another important non-dimensional physical constant, namely, the ratio of the mass of the proton to that of the electron, $M / m$, cannot be accounted for by counting up elements and by performing simple operations with the numbers so obtained. If so, it is plausible to assume that $M / m$ should depend on two such numbers, one of them being 136. The other number here taken is 10 , as the absence of protonic spin hints at the smaller value. With these two integers on hand, and with the observed value of $M / m$ (1840, roughly) in mind, it is tempting to write :

$$
M=\frac{(136)^{2}}{10}=1849 \cdot 6 \text {. }
$$

I am aware of no proof of this relation. But as I do not, at present, know of any reason for ascribing the numerical result, without at least some hesitation, to a mere coincidence, I believe that the numerical agreement in this 'empirical ' relation warrants notice.

Washington University, V. Rojansky.

$$
\begin{gathered}
\text { St. Louis, U.S.A., } \\
\text { April } 26 .
\end{gathered}
$$

\section{Freshwater Medusæ in England.}

IN Nature for Jan. 12, Prof. Hickson has recorded freshwater medusæ and their polyps from Mr. V. B. Poulton's aquarium at Boscombe. Afterwards these were assigned to Craspedacusta sowerbii after comparison with drawings made at the British Museum of polyp stages of that species found last summer on Pandanus roots in the Victoria regia tank of the Royal Botanic Society and exhibited at a meeting of the Zoological Society.

The Boscombe polyps afford additional confirmation of the evidence for linking up Sir Ray Lankester's Regent's Park medusa with the polyps of Bourne, Parsons, and Fowler, since they bear medusa-buds.

In case any other amateur should observe freshwater medusæ in England it is to be hoped that it will occur to him to communicate with the British Museum. It seems highly probable that Craspeda. custa occurs in a wild state in British river systems, and it would be well if a sharp look out for it were maintained.

British Museum (Natural History),

$$
\text { A. K. TоттоN. }
$$

London, S.W.7, May 13.

\section{The Crystal Structure of Nickel Films.}

Finms of nickel deposited on rock salt by spluttering in residual gas or argon, show an unexpected structure on removal from the rocksalt and examination by the cathode ray diffraction method. As is well known, the normal structure of nickel is face centred cubic, as found both by $\mathrm{X}$-ray and electron diffraction methods. The new structure turns out to be hexagonal, the values of the axes being $c=4.06 \mathrm{~A}$., $a=2 \cdot 474 \mathrm{~A}$. ratio $1 \cdot 64$, which is near enough to the ratio 1.633 for closest packing. Nickel thus resembles cobalt in crystallising in both cubic and hexagonal closest packing. The density calculated from the above axes is 8.86 , in good agreement with that of the metal in bulk. The structure is thus different from an hexagonal form found by Bredig and Allolio (Zeit.f. Phys. Chem., 126, p. $53 ; 1927)$ by spluttering in hydrogen. The latter had a density of only 7.04 and is probably a hydride. The above is, I believe, the first case of a new crystal form found by electron diffraction.

University of Aberdeen,

G. P. Thomson. May 31 .

\section{A Proposed Survey of the Burnet-moths.}

I AM at present undertaking a survey of the variations in the male and female genitalia and in the wing patterns in the genus Zygcena, or Burnet-moths. This necessitates the collection of specimens from as many parts as possible of the British Isles and continent of Europe. I should therefore be very grateful if specimens could be sent to me this summer. They should be taken in pupa and, if possible, at least two dozen from one locality or colony. It is very necessary that pupæ from neighbouring or different colonies should be kept separate. Details as to the position and extent of the colonies would be welcome so that they can be identified afterwards on Survey maps. Pupæ may be taken on the grass stems, packed in a small box and sent to the address below. Due acknowledgments to the collectors will be made of course in resulting publications.

Department of Zoology,

H. R. HEwER.

Imperial College of Science and Technology, South Kensington, London, S.W.7.

The Emission of Positive Ions from Metals.

DURING the study by me of critical potentials in metallic vapours (Phys. Rev., August 1928), it was noticed that positive ions were given off by heated metals and that these ions persisted for very long periods of heat treatment. A determination of $\mathrm{e} / \mathrm{m}$ of the positive ions from heated metals gives the following results. Copper, iron, nickel, and platinum when heated, give alkaline ions only, as has been found by other observers. Tungsten, molybdenum, and tantalum when heated to a temperature where vaporisation becomes appreciable, give ions the atomic weights of which agree with that of the metal emitting them. Other metals are under investigation.

University of Wisconsin,

H. B. WaHLIN. Madison, Wisconsin, U.S.A.

\section{Adder or Nether.}

IN his note upon dragonflies in Nature of Jume 1, Dr. Tillyard asks whether the adder is still called the 'ether' in any part of England. I cannot answer for England, but 'nether' is good Lowland Scots for 'adder', and is given in that sense in Jamieson's "Dictionary of the Scottish Language". Among examples given by Skeat of initial $n$ shifting from the noun to the indefinite article, or from the article to the noun, he mentions addere and naddere as interchangeable forms in Middle English; but he. says nothing on the question whether 'adder' comes from Anglo-Saxon neoðera, nether-the lowly one.

Monreith, Wigtownshire.
Herbert Maxwell.

No. 3111, VoL. 123] 